\title{
The Washback Effect of WAEC/SSCE English Test of Orals on Teachers Methodology in Senior Secondary Schools in Sokoto Metropolis
}

\author{
Ibrahim A.A. ${ }^{1} \&$ Bello $\mathrm{U}^{2}$ \\ ${ }^{1}$ Department of Curriculum Studies and Educational Technology, Usmanu Danfodiyo University, Sokoto, Nigeria \\ ${ }^{2}$ Curriculum Studies Department, Sokoto State University, Sokoto, Nigeria \\ Correspondence: Ibrahim A.A, Department of Curriculum Studies and Educational Technology, Usmanu \\ Danfodiyo University, Sokoto, Nigeria
}

Received: October 11, 2019

Accepted: December 27, 2019

Online Published: December 30, 2019

doi: $10.5539 /$ elt.v13n1p180

URL: https://doi.org/10.5539/elt.v13n1p180

\begin{abstract}
The study investigates the washback effect of WAEC/SSCE English Test of Orals on Teachers Methodology. The method used in this research is a mixed method employing survey and case study strategies. Questionnaire and semi- structured interview were used to collect data. 32 out of the 41 teachers of English taking senior secondary school classes in Sokoto metropolis were sampled to respond to the questionnaire and the selection of participants was done using random sampling method. 5 teachers of English outside the sampled population were purposively selected to participate in the interview. The data from the questionnaire was analyzed quantitatively using frequencies, simple percentages and mean ranking while the data from the interview was analyzed qualitatively. The findings were presented sequentially, quantitative followed by qualitative. The result obtained from the study revealed that examination related factors affect the teachers in their choice and use of methodology the more. Teachers follow the format of the test and skip other content in the curriculum that did not feature in the test. The research concludes that the practice constitutes negative washback on teaching methodology and that examination bodies must improve on their testing system for the attainment of the envisaged positive washback.
\end{abstract}

Keywords: washback, oral language, teachers' methodology, high stake examinations, communicative competence

\section{Introduction}

\subsection{Background to the Study}

Washback is a well-studied concept referring to the effect of a test on teaching and general educational practices. It is a known fact that high stake test propels teachers and educators to change their ways of doing things to the demands of the test. Such examinations usually assert great deal of influence on the how (methodology) and what (content) of teaching and other educational practices. Hughes (2003) indicates that if a test is regarded as important, if the stakes are high, preparation for it can come to dominate all teaching and learning activities. This phenomenon where teaching is influenced by a test especially the high stake ones such as the West African Examination Council(WAEC) Senior Secondary Certificate Examination (SSCE) English Test of Orals is referred to as Washback. examination Washback has been reported severally to affect classroom teaching in different studies and contexts. In Nigeria specifically in Sokoto STATE ever since the introduction of West African Examination Council (WAEC) Senior Secondary School Certificate Examination (SSCE) Test of Orals in 1995, little or no research is conducted to ascertain how the examination may have affected teachers' classroom practices, such as teacher' choice and use of teaching methodology.

This effect induced on teachers' practices as a result of the introduction of a test could either be positive or negative. This means that washback is bidirectional (negative or positive). For a test to have positive washback, there should be little difference if any between activities and content involved in teaching and the activities and content involved in the test. The activities in themselves must be such that they reflect the right construct and the course objectives for it to attract positive effect. This is to say the construct for which the test is meant to test must be duly represented. If, however, construct under representation or construct irrelevance exists in a test there is a tendency that the teaching would be adversely affected. 
However, it is possible to find a poor test seemingly having positive effect and a good test having negative effect. In this case, some intervening variables beyond the exam per se may have contributed to determining or precluding the amount and kind of washback impact (Spratt, 2005). We can therefore refer to washback as consequence of a test if only it can be evidentially testified as coming from the test. When investigating washback therefore, aside from observing teachers in class, it is important to find out from the teachers themselves what could be responsible for their choice of teaching strategies and activities.

In determining whether washback occurs, the construct for which the test is meant to test must therefore be defined. In Second Language testing situation the construct that any test is supposed to test is the construct of communicative competence which is best assessed through performance (Bagarić \& Djigunović 2007). This is because testing learners' linguistic competence alone as the case with many examinations such as WAEC test of orals is not adequate. Pillar (2011) in regards to this says "the notion of communicative competence evolved in order to account for the fact that linguistic competence alone does not adequately account for how language is used". Ahmad \& Rao (2012) submit also that the theoretical principle that should guide a good test of Second or Foreign Language should be that of communicative competence since according to them Communicative Competence has currently replaced Linguistic Competence in language Testing. Since the WAEC test of orals is aimed at testing learner ability to produce intelligible utterances in speech (WAEC SSCE English Language Syllabus, 2018), the construct is better assessed through productive and receptive skills (speaking and listening) respectively. Olaofe (2013) indicates that speech training should include conversational skills not only understanding. It should include according to him both receptive and productive skills. Fasanmi (2011) states that teachers need to take the learners to a state of proficiency that bridges the linguistic and communicative gaps between the two interlocutors in speech acts.

Despite the importance of testing and teaching actual oral skill through exposure to meaningful use of the language in Oral English class in Sokoto State, most teachers only restrict themselves to the teaching of segmental and supra segmental features in isolation. Olaofe (2013) in regards to this notes "in most of the adverse English Language teaching situations in Nigeria, speech work is reduced to merely sporadic treatment of segmental sounds in isolation". Teachers in most of these classrooms gather the individual sounds and their phonetic symbols and present same to students for identification and recognition. Most of these teachers do not bother to consider as part of speech work engaging their students in listening, debate and dialogues etc. which are integral part of oral component to the Senior Secondary school English curriculum. In agreement with the curriculum, Saif (2011) asserts "it is only by incorporating the speaking and listening skills into periodic tests and/or final examinations, can teachers send the right message to students (learning washback) regarding the importance of communicating in the target language".

Is this situation the result of the change as brought about by the introduction of WAEC Test of Orals in 1995 or is it coming from other factors? This study is therefore conducted to ascertain whether what teachers do in class as per their methodology is the result of the test (WAEC Test of Orals or other factors. It is also to find how the examination affects teachers' choice and use of methodologies.

\subsection{Aims and Objectives}

The aim of the study is to explore the actual influence of WAEC SSCE English Language Test of Orals (washback) on teacher methodology and to assess the direction of the washback. The specific objectives of the study therefore are:

1. to find out the factors that guide the teachers' choice and use of methodology in teaching Oral English

2. to investigate how the WAEC SSCE Test of Orals affects the teachers' choice and use of methodology

3. to assess the direction of the influence (positive or negative)

\subsection{Research Questions}

1. What factors affect the teachers' choice and use of methodology in teaching Oral English?

2. How does the WAEC SSCE Test of orals affect the teachers' choice and use of methodology in teaching Oral English?

3. What is the direction of the influence (positive or negative)?

\subsection{Significance of the Study}

Teachers believe that teaching to the test is the best way of teaching whether or not the test addresses the various components of the curriculum and course objectives. This study therefore is intended to enlighten English language teachers and other stake holders become aware of the existence of washback and the negative 
consequence of tailoring teaching solely to the demands of the test ignoring the provisions of the curriculum and course objectives. It is hoped that the findings of this study will also enlighten test developers and researchers about washback as a consequence of and an integral part of any validity claim. It is also intended to provide valuable information to encourage examination bodies and other stake holders improve on the testing system in the country to ensure that all tests are designed in such a way that they will induce positive washback on teaching. Lastly and most importantly, it is hoped that the research will add to the existing literature

\section{Literature Review}

\subsection{Washback}

Xie, (2013) \& Onaiba (2013) refer to Washback as the educational phenomenon that describes the influences of tests on teaching and learning. Washback according to Messick (1996) is "the extent to which the introduction and the use of a test influence language teachers to do things they would not otherwise do that promote or inhibit language learning". Hughes (2003) states "the effect of testing on teaching and learning is known as washback". Amengual-Pizarro (2009) \& Stecher et al. (2004) found that teachers changed their methods to reflect test requirements.

Wall (2005) asserts that tests have debits as well as credits supporting the notion that washback is bi-directional (Cheng \& Curtis, 2004). The fact that washback could have credit or debit makes it to be termed as the positive or negative effect tests may have on teaching and learning. For example, Onaiba, 2013 observed negative washback as the exam he studied did not reflect the curriculum. Cheng, 2005 Observed that the Studied test encouraged teachers to pay more attention to the oral and integrated skills components tested in the test. While Huges, (2003) observed that preparation for the test in focus dominated all teaching and learning activities in the classroom. Brijand, (2015) observed grammar-translation method to be the dominant methodology in all classrooms as the test was based on testing learners' ability to translate and explain grammar. Chih- Min S. (2009) Found that while test effects are insignificantly present, micro-level contextual factors (for example, the objectives of the course) and teacher factors such as teacher training and quality had a greater impact on teachers' instruction.

However, contrary to expectations, some studies found no relationship between teachers' method of teaching and introduced test. For instance, Cheng (2005) observes that the way a teacher carries out his/her teaching remained more or less the same, whether the testing syllabus was the old one or the new one. Watanabe (2000) also found that teachers deliberately avoided test taking techniques, since even the actual teaching of English skills would lead students to success in the examination. This observation by Watanabe only remains true if the test captures those 'actual skills' that a language test especially in second or foreign language situation requires to test.

Factors other than exam itself could intervene in making decision as to whether the changes reported in a washback study actually come from the exam per se or from some extraneous variables. Wall (2012) pointed out that there is difficulty in separating out the influence of tests from the effects of other variables at work in the educational contexts. Among the characteristics are teachers' beliefs, perceptions, experience, academic qualifications and educational backgrounds as well as training and teacher- gender related influences (Shazadi, Khatoon, Aziz \&Hassan 2011). Also Cheng (2008) states that teacher factors, including personal beliefs, past education, and academic background, seemed to be more important in determining the teaching methodology a teacher employs. This means in determining washback effect, it is important to isolate these variables before making a stand on whether or not what teachers do or undo is the result of the test under study.

More often than not Washback is seen to be confined only to the unforeseen and unintended effects and not to the intended effects of tests. However, there seems to be a consensus among educators that washback is any effect, positive or negative, intended or unintended that are induced on teaching and learning as a result of administering examinations (Hughes, 2003; Cheng \& Curtis, 2004; Cheng, 2008; Cheng, 2005; Bachman \& Palmer, 2010; Hung, 2012). For example, Cheng, (2008) maintains that there is a set of intended and unintended, positive and negative relationships between testing, teaching and learning.

\subsection{Oral Language}

Oral language is the primary means through which each individual child will be enabled to structure, to evaluate, to describe and to control his/her experience (Archer, Cregan, McGough \& Shiel 2012). According to Laurent (2015), "Oral language is the system through which we use spoken words to express knowledge, ideas, and feelings". It is about communicating with other people involving a process of utilizing thinking, knowledge and skills in order to speak and listen effectively (PDST, 2014). This means that the linguistic competence acquired by the learner (in Phonetics and Phonology, Syntax and Morphology) be put to use as learners venture to transact 
in oral discourse. This goes with idea of Moat (2010) where he advances five key components of oral language to include: phonological, pragmatic, syntactic, morphological and semantics (vocabulary) skills. The inclusion of 'Pragmatics' by Moat (2010) makes acquisition of oral language not purely a business of acquiring the formal language skills as in Phonology, Syntax, and Morphology but also acquisition of practical skills that will ensure meaningful use of the language in interaction and transaction.

\subsection{Instructional Methodology}

Instruction starts with the curriculum to actual classroom delivery which consists in "teaching methods, techniques and activities teachers use or adhere to in their instruction (Onaiba 2013). These all constitute methodology washback. A method in Second language teaching is a plan for presenting language materials to be learnt based on selected approaches (Oaofe 2013). It is according to him translating an approach or theory of Second language teaching into an instructional system based on the objectives of language learning, content to be learnt, types of tasks/activities and techniques to explore. Set of tasks and activities that are related and used in a teaching encounter are referred to as techniques. A Technique is a precise strategy, a known trick that is used within the framework of a particular method (Olaofe 2013). Activities are what teachers and students do in class to teach and practice a particular language use or usage respectively (Richards, 2006). Teacher methodology therefore involves choice and use of content, methods and techniques in a Second/foreign language teaching encounters.

\section{Methodology}

\subsection{Research Design}

The research design to be used in this study are survey and case study. As data obtained from survey are analyzed quantitatively and that of case study qualitatively, the method employed in this study is therefore a mixed-method that involves the use of questionnaire and interview respectively.

\subsection{Participants}

The participants used in this study were Senior Secondary School teachers of English Language in Sokoto metropolis. As per the list supplied by the Sokoto South Zonal Education office there 41 Senior Secondary School teachers of English Language in the metropolis. A sample size calculator at (https://www.calculator.net/sample-size-calculator) was used to arrive at the sample size of 32 teachers to serve as representative of the larger population which was 41 . Using a randomizer at https://www.randomizer.org/\#randomize the 32 were randomly selected to participate in the survey. Additional 5 teachers of English were purposively selected outside the sampled population to participate in the interview.

\subsection{Instrument for Data Collection}

A self-structured 1-5 points Likert's Washback Effect of WAEC SSCE English Language Test of Orals on Teacher Methodology (WEWELTOTM) was used to collect qualitative data. An interview guide for the semi-structured interview was used to delve deeply into the issue at hand without restrictions that are usually posed by the questionnaire.

\subsubsection{Validity of the Instrument}

Trialing was used to validate teacher questionnaire. This was done by administering the tool to 5 teachers outside the targeted sample to respond in order to find out whether teachers understood each question as intended by the researcher, and whether the items were understood the same way by each teacher (Dornyei and Taguchi, 2010). As a result of the trialing, some questions were reframed for their lack of clarity while others thrown out.

\subsubsection{Pilot Study}

A pilot study was conducted in 5 schools in Sokoto North Educational zone involving 15 English Language teachers. The selection of teachers from the zone was informed by the fact that they share the same characteristics with those of the population used in this study for both of whom teach within the metropolitan city of Sokoto and suburbs.

\subsubsection{Reliability of the Instrument}

Using the Pearson Product - Moment Correlation Coefficient, the reliability of the instrument was found to be 0.755 calculated at 0.01 significant level ( 2 tailed) which was good enough to consider the instrument reliable.

\subsection{Method of Data Analysis}

With the help of SPSS software, frequencies, percentages and mean ranking were used to analyze quantitative data. For the semi structured interview, an interview guide was used to help the researcher not to digress from the research concerns. The qualitative data obtained from the case study (interview) was recorded digitally. The 
findings were compiled by identifying categories and themes that match the research questions (Silverman, 2010). Afterwards, data reduction, data display, conclusion drawing and verification was done concurrently (Onaiba, 2013). All the findings of the research were presented sequentially (quantitative followed by qualitative).

\section{Result and Analysis}

\subsection{Factors Affecting Teachers Choice and Use of Methodology}

As not just the examination but other intervening factors could affect what teachers do in class, this section looks at those factors as they affect teachers' methodology. Seven possible factors were presented in the instrument. They were WAEC syllabus/ past question papers, curriculum, teachers' educational beliefs, available teaching materials in the school, WAEC examination guide textbooks, nature and size of class, teachers experience and expertise. Table 2 below shows the mean score distribution of the factors.

Table 1. Mean score distribution of the factors affecting teacher's methodology

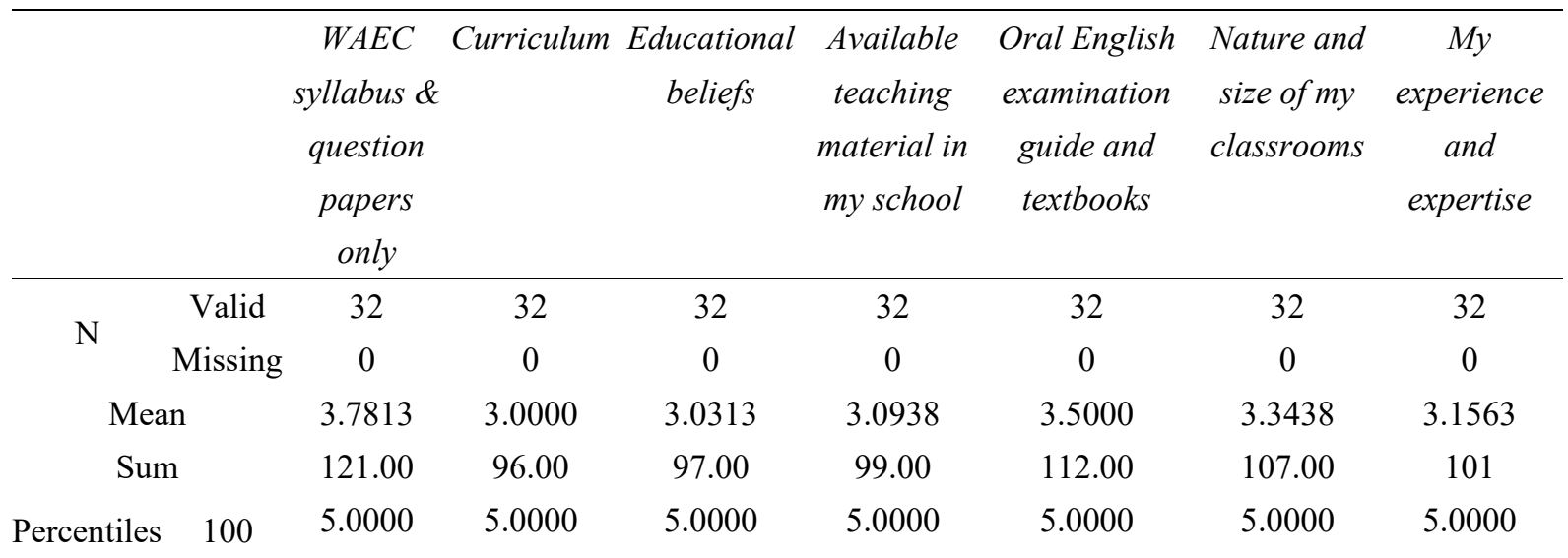

It is clearly seen from table 2 above that WAEC test of orals related responses which include examination guide textbooks, syllabus and past question papers are the most favored responses with mean score of 3.5 and 3.8 respectively. Since the non- examination related practices have also mean score above 2.50 , they also could be considered among the factors responsible in shaping what teachers do in class as per teaching oral English. As questionnaires are restrictive, the semi- structured interview conducted helped the researcher to delve deeply into the matter by allowing new ideas from the respondents. The outcome of the interview verified the findings of the quantitative survey. Most of the teachers interviewed are of the view that since they are dealing with senior secondary school classes, they concentrate on WAEC syllabus in their choice of methods, content and techniques.

Below are some of the responses of some teachers interviewed:

T1: I refer to WAEC syllabus to get topics for my teaching since it is only in SS2 that I have enough time to teach and since there is no time, if you are to pay attention to other materials you may not succeed in coaching your students to pass WAEC. My experience at times also counts.

T4: Curriculum provided by the school, but when we are close to final exam, I use question papers to practice oral English.

T5: I will look at the curriculum but will concentrate more on the provision of the examination syllabus because the aim is to make my students pass out of the school with good result.

\subsection{How the WAEC Test of Orals affect Teachers' Teaching Methodology (Methods, Content and Materials)}

Choice of methods, content and materials constitute teacher methodology. The various practices relating to method, content and materials are represented in the teacher questionnaire. The responses by the teachers are tabulated and presented based on favorability or otherwise of the items/variables. Table 3 below presents the percentages and mean ranking of the different activities/techniques, content and materials teachers possibly use in their teaching of oral English. 
Table 2. Percentage distribution and mean ranking of responses to RQ2

\begin{tabular}{|c|c|c|c|c|c|c|c|c|}
\hline & Variables & $S D$ & $D$ & $U D$ & $A$ & $S A$ & Mean & Rank \\
\hline 1. & $\begin{array}{l}\text { I often have my students identify English } \\
\text { sounds and their corresponding phonetic } \\
\text { symbols. }\end{array}$ & $0 \%$ & $18.8 \%$ & $0 \%$ & $43.8 \%$ & $37.5 \%$ & 4.000 & 1 \\
\hline 2 & $\begin{array}{l}\text { I teach all the other aspects found in the } \\
\text { curriculum but lay more emphasis on aspects } \\
\text { in the test(WAEC Test of Orals). }\end{array}$ & $2 \%$ & $9.4 \%$ & $0 \%$ & $52 \%$ & $35.6 \%$ & 3.953 & 2 \\
\hline 3 & $\begin{array}{l}\text { All I do is engage my students in multiple } \\
\text { choice, gap filling/completion exercise and } \\
\text { Oral drills using isolated words and symbols }\end{array}$ & $4 \%$ & $15.5 \%$ & $5 \%$ & $54 \%$ & $21.5 \%$ & 3.735 & 3 \\
\hline 4 & $\begin{array}{l}\text { I very often use WAEC past question papers } \\
\text { to practice Oral English with my students }\end{array}$ & $8 \%$ & $12 \%$ & $0 \%$ & $54.4 \%$ & $25.6 \%$ & 3.729 & 4 \\
\hline 5 & $\begin{array}{l}\text { It makes me ignore other aspects not found in } \\
\text { the test of orals(WAEC). }\end{array}$ & $0 \%$ & $35.2 \%$ & $8.8 \%$ & $42.6 \%$ & $13.3 \%$ & 2.968 & 5 \\
\hline 6 & $\begin{array}{l}\text { I organize group work in my oral English } \\
\text { classes. }\end{array}$ & $17 \%$ & $32.7 \%$ & $! 0.3 \%$ & $25 \%$ & $15 \%$ & 2.883 & 6 \\
\hline 7 & $\begin{array}{l}\text { I mostly consult WAEC syllabus more than I } \\
\text { do the curriculum for my oral English class. }\end{array}$ & $25.3 \%$ & $25 \%$ & $22.2 \%$ & $22.5 \%$ & $5 \%$ & 2.569 & 7 \\
\hline 8 & $\begin{array}{l}\text { I do engage my students in oral compositions } \\
\text { and conversations in my oral English classes. }\end{array}$ & $21 \%$ & $43 \%$ & $4.4 \%$ & $22.6 \%$ & $9 \%$ & 2.555 & 8 \\
\hline 9 & $\begin{array}{l}\text { I give equal treatment to all the aspects } \\
\text { involved in oracy development even if not } \\
\text { found in the test(WAEC test OF orals). }\end{array}$ & $25 \%$ & $49.4 \%$ & $0 \%$ & $15 \%$ & $10.6 \%$ & 2.368 & 9 \\
\hline 10 & $\begin{array}{l}\text { I often engage my students in oral debate in } \\
\text { my Oral English class. }\end{array}$ & $7 \%$ & $67 \%$ & 10.4 & $15.6 \%$ & 0 & 2.346 & 10 \\
\hline 11 & $\begin{array}{l}\text { Listening and speaking activities dominate } \\
\text { my class }\end{array}$ & $35.7 \%$ & $32 \%$ & $0 \%$ & $22 \%$ & $10 \%$ & 2.340 & 11 \\
\hline 12 & $\begin{array}{l}\text { I use authentic video/audio (e.g. English } \\
\text { movies) in my Oral English classes. }\end{array}$ & $32 \%$ & $41 \%$ & $0 \%$ & $! 6.2 \%$ & $10.8 \%$ & 2.328 & 12 \\
\hline
\end{tabular}
N 32

It is clear from the table above that the examination -related practices are ranked higher than the non-examination related practices. It can also be seen that where the mean is higher, the percentage towards disagreeing with the items is lower, vis - a- vis where the mean is lower the percentage towards disagreeing with the item is higher. By this it is meant that greater percentage of the favorable responses are with the examination related practice while the non- examination practices attract greater percentage of the unfavorable responses. More teachers indicate a high inclination to examination related practices geared towards ensuring that students become familiar with the pattern and techniques used in the WAEC SSCE Test of Orals. The practice with the highest mean has mean value of 4.000 whereas the least has the mean value of 2.328 . Table 3 , shows the frequency and percentage distribution of the most favored practice/activity adopted by the teachers. 
Table 3. frequency of the highest ranked activity (Having students identify sounds and their symbols)

\begin{tabular}{|c|c|c|c|c|}
\hline & & Frequency & Percent & Valid Percent \\
\hline \multirow{7}{*}{ Valid } & Strongly & 0 & 0 & 0 \\
\hline & Disagree & & & \\
\hline & Disagree & 6 & 18.8 & 18.8 \\
\hline & Undecided & 0 & 0 & 0 \\
\hline & Agree & 14 & 43.8 & 43.8 \\
\hline & Strongly Agree & 12 & 37.5 & 37.5 \\
\hline & Total & 32 & 100.0 & 100.0 \\
\hline
\end{tabular}

From the table above, it can be seen that the practice with highest ranking is examination related. $\quad 31.3 \%$ and $34.4 \%$ of the teachers went with 'agree' and strongly agree respectively. The sum total of the percentage of the favorability towards the item is $65.7 \%$ where as $28.1 \%$ disagree and only $6.3 \%$ remained undecided.

Table 4. frequency distribution of the least ranked practice (Use of authentic video/audio e.g. English movies)

\begin{tabular}{ccccc}
\hline & & Frequency & Percent & Valid Percent \\
\hline \multirow{7}{*}{ Valid } & Strongly & 10 & 32 & 32 \\
& Disagree & & & \\
& Disagree & 13 & 41 & 41 \\
& Undecided & 0 & 0 & 0 \\
& Agree & 5 & 16.2 & 16.2 \\
& Strongly Agree & 4 & 10.8 & 10.8 \\
\cline { 2 - 5 } & Total & 32 & 100.0 & 100.0 \\
\hline
\end{tabular}

The practice with the least ranking is non- examination related. It has the highest frequency towards disagreeing with the item. 23 respondents out of 32 went with disagree, representing $73 \%$ while 19 respondents went with agree representing $27 \%$.

The findings of the quantitative data above are in consonance with what was uncovered by the interviewees when they responded to the following specific questions:

1. Explain clearly how you teach oral English

T1: I present a sound with its sign, pronounce the sound and student will repeat after me. Then I give example of words containing the sound. I will do like that with the remaining sounds.

T4: I drill students on the pronunciation of the sounds orally and then show them example using words that contains the sound and then give exercise... (of what sort?) fill in blanc and objectives. At times I ask them to give words that have a particular sound etc.

T5: I define and explain to them the topic and then ask them to pronounce sounds in words and in sentences. Before I finish I give them exercise....... (what type?) I give them exercise from WAEC questions.

2. Has the WAEC test of Orals exam led to your using a particular teaching method, content and materials which you otherwise wouldn't have used? (if yes) How?

T4: Yes of course. Since my students passing the exam is my priority I should use a method that will make my students pass the examination. For example, I use fill in the blank exercise, objectives and make my students to know how to pronounce sounds by asking them to repeat after me so that when they see a sound in their WAEC they should be able to recognize it in words.

T1: Most of the exercises that I do I got them from the WAEC past question papers. When students master how to answer such questions, they can easily pass the examination.

3. How often do you engage your students in oral production activities (speaking) and listening in an oral English class? 
T5: Not always because we don't have materials e.g. tape recorder.... (what about speaking?) I teach all the sounds, consonant and vowels.... (I mean actual speaking such as in conversation, debate etc.) Oh! such are not part of Oral English. I teach that when I am teaching argumentative essay for example.

T2: Yes, they need to be taught but they are not examined in all the final examinations and since we cannot cover all that is in the curriculum, I teach them what I feel they need to know to pass the examination. I don't honestly teach such especially listening but actual speaking, when we are doing debate I teach it.

T4: Listening, I don't teach listening but at times I teach speaking because I usually ask students to stand before the class to speak on a topic... (why don't you teach listening?) because we don't have tape recorder and besides it is not tested in the final examinations so I don't ...

\section{Discussion}

The result from both the case study and survey (interview and questionnaire) has revealed more teachers' methodologies inclined towards practicing examination type activities and techniques. The description given by the teachers' in the interview as to how they teach oral English has further revealed and confirmed the result from the quantitative survey where the examination - related practices have surpassed the non-examination related ones in terms of their mean value. Since the focused exam is purely in multiple choice items format, most of the teachers tailor their teaching towards teaching isolated sound segments. This goes with Pan (2013); Brijand (2015); Wall (2009); Chin - Min (2009) that teachers adopted test format in their teaching.

However, while a study in Hong Kong by Hong (2005) indicates that the test he studied encouraged teachers to pay more attention to the oral and integrated skills, the present study reveals that teachers pay attention to oral drills and exercises in isolation instead. This is indeed a negative influence in that such isolated oral drills usually do not alone represent the defined construct in oracy development. The above responses also further clarify what was found from the quantitative data where exams related practices are ranked higher than non-examination related ones.

Teachers' selection and use of content, were also found to be aligned not with all the provisions of the curriculum and course objectives. From both the quantitative and qualitative analysis conducted, greater percentage of the teachers, skip listening and actual speaking skills in their teaching because it is not being tested in the test. This results in what Pan (2013) calls 'curriculum alignment'. This finding coincides with those of (Onaiba 2013; Brijand 2015) that the examinations they focused on exerted washback on teachers' instructional content, and materials. As the focused examinations did not represent the curriculum, negative washback is therefore reported.

While the teachers indicated that they engage their students in activities and choose content similar to that of the WAEC, other factors such as time constraint trigger them to also align their teaching with the examination.

\section{Conclusion}

Having established the fact that test could affect teaching in positive or negative ways from the various literatures and similar studies consulted, this study further substantiated the fact. Although the examination bodies responsible for these high stake tests usually envisage that their test should bring about positive influence, close investigation of the focused exam shows debits rather than credits. This study has brought to fore the fact that without conducting investigations of this nature, the examination bodies will continue to be chasing shadows as far as producing positive consequences of their examinations on teaching and learning.

Specifically, the study has succeeded in unfolding the fact that aside from the deficiency of the studied test in representing the construct of communicative use of the oral language in its entirety, it has also had far reaching negative consequence on teaching. It has incited teachers to want to teach only those aspects found in the test ignoring other skills that are involved in oracy development such as listening and speaking. Its discrete point nature makes it invalid as to assess learners' oral abilities because directness and authenticity which are absent in the test have been adjudged amongst the characteristics of a good language test.

\subsection{Limitation of the Study and Recommendation for further Research}

This study is limited in the population size for it covers only Teachers of English Language within Sokoto metropolis which due to constraints of time and cost, the researcher could not have covered the whole of Sokoto State or Nigeria in general. What is also missing in this study is its inability to benefit from observational data which was needed by the researcher to observe first hand evidence of washback and to make the evidence clearer. The research was also limited to studying only the Oral Component of The WAEC/ SSCE examination. It would therefore be worth replicating this study on the other Components of the examination on larger population and 
different contexts in Nigeria Other aspects of Washback such as washback effect of examination on teachers' perception, learning, the society and other educational practices could also be studied.

\section{Acknowledgement}

The researchers acknowledge the contribution of the affected school authorities for giving their consent to have access to English Language teachers in their domain. Most importantly, we are thankful to all the teachers who participated in the survey and interview.

\section{References}

Ahmed, S. \& Rao C. (2012). A review of pedagogical implication of examination washback. Research in Humanities and Social Sciences, 2(7), 14-15. https://www.researchgate.net/publication/301338236

Amengual-Pizarro, M. (2009). Does the English test in the spanish university entrance examination influence the teaching of English? English studies, 90(5), 582-598. https://doi.org/10.1080/00138380903181031

Archer, P. Cregan, A., McGough, A. \& Shiel, G. (2012). Oral language in early childhood and primary education (3-8 years). Dublin, NCCA. Retrieved from https://www.ncca.ie/media/2149/oral_language_in_early_childhood_and_primary_education_3-8_years_p df on 27th January, 2019.

Bachman, L.F. \& Palmer, A. (2010). Language assessment in practice: developing language assessments and justifying their use in the real world, Oxford: Oxford University Press.

Birjand P. \& Taqizadeh M. (2015). What drives high school English teachers to teach the way they do? An investigation of the washback effect of the university entrance examination in Iran. Journal of Applied Linguistics and Language Research, 2(2), 8-20. Retrieved from www.jallr.com/index.php/JALLR/article/download/28/pdf_25 on 21 ${ }^{\text {st }}$ Sept, 2018.

Bagarić, V. \& Djigunović, M. (2007). Defining communicative competence. Metodika, 8(1), 94-103. Retrieved from https://hrcak.srce.hr/file/42651 on $25^{\text {th }}$ January 2017.

Cheng \& Curtis, A. (2004). 'Washback or washout: A review of the impact of testing on teaching and learning.' in Cheng, L. Watanabe, L., Y., and Curtis, (ed.) Washback in language testing: Research context and methods., Mahwah New Jersey USA: Lawrence Erlbaum Associates, 3-17

Cheng, L. (2005). Changing language teaching through language testing: A washback study, Cambridge University Press.

Cheng, L. (2008). Washback, impact and consequences. https://doi.org/10.1007/978-0-387-30424-3_186

Chih-Min S. (2009). How tests change teaching: A model for reference. English Teaching: Practice and Critique, 8(2), 188-206. Retrieved on $2^{\text {nd }}$ December 2018 from https://files.eric.ed.gov/fulltext/EJ859684.pdf

Donyei, Z. \& Taguchi, T. (2010). questionnaires in second language research: construction, administration \& processing. Taylor \& Francis, London, UK. https://doi.org/10.4324/9780203864739

Fasanmi, O. (2011). Challenges of oral English in English as a Second Language (ESL) Learning in Nigeria. Academic Leadership: The Online Journal, 2(9), article 11. https://scholars.fhsu.edu/alj/vol9/iss2/11

Hughes, A. (2003). Testing for language teachers, 2nd ed. Cambridge: Cambridge University Press. Retrieved from catdir.loc.gov/catdir/samples/cam034/2003268576.pdf on 12 ${ }^{\text {th }}$ September 2018.

Hung, S.-T. A. (2012). A washback study on e-portfolio assessment in an English as a Foreign Language teacher preparation program. Computer Assisted Language Learning, 25(1), 21-36. https://doi.org/10.1080/09588221.2010.551756

Laurent A. (2015). What is oral language? Heinemann blog. Retrieved on 4th May, 2019 from https://blog.heinemann.com/what-is-oral-language

Messick, S. (1996). Validity and washback in language testing. Language Testing, 13(3), 241-256 from https://www.ets.org/Media/Research/pdf/RR-96-17.pdf https://doi.org/10.1177/026553229601300302

Moat L.C. (2010). Speech to print: Language essentials for teachers. Baltmore, Paul Brook.

Nigerian educational research and development council (NERDC, (2012). senior secondary school curriculum, English Language.

Olaofe, I. (2013). Teaching English in second language adverse situation: A solution - based approach. Applied Linguistics and language education center, Zaria, Nigeria. 
Onaiba, A.M.E. (2013). Investigating the washback effect of a revised EFL public examination on teachers instructional Practices, materials and curriculum. A doctoral thesis, University of leicester, UK. https://hdl.handle.net/2381/28561

Pan Y.C. (2013). Does teaching to the test exist? A case study of teacher washback in Taiwan. The Journal of Asia TEFL, 10(4), 185-213.

Pillar G.W. (2011). A framework for testing communicative competence. The Round Table: Partium Journal of $\begin{array}{lllll}\text { English } & \text { Studies, } & 24 & \text { Retrieved } & \text { from }\end{array}$ http://theroundtable.partium.ro/Current/Language/Granville_Pilar_Framework_for_Testing_Communicativ e_Competence.pdf

Professional Development Service for Teacher (PDST) (2014). Five components of effective oral language instruction: A Guide to the teaching and learning of oral language, Dublin. Retrieved from www.pdst.ie/sites/.../Five\%20ComponentsOral\%20Language.pdf

Richards J.C. (2006). Communicative language teaching today. Cambridge University Press, NewYork, NY

Saif, S. (2011). A Needs-based approach to the evaluation of the spoken language ability of international teaching assistants. RCLA CJAL, (5), 1, https://www.researchgate.net/publication/260790628

Silverman, D. (2010). Doing qualitative research: a practical handbook, 2nd ed. Thousand Oaks, CA.; London: Sage.

Spratt, M. (2005). Washback and the classroom: the implications for teaching and learning of studies of washback from exams. Language teaching research, 9(1), 5- 29. https://doi.org/10.1191/13621688051r152oa

Shazadi, T. Khatoon, S. Aziz, S. \& Hassan, H. (2011). Determining factors affecting teachers' self-efficacy at secondary school level. Language in India, 11(10), 385-395.

Wall, D. (2005). The impact of high-stakes examinations on classroom teaching: a case study using insights from testing and innovation theory. Cambridge, Cambridge university press. https://www.researchgate.net/publication/35728067

Watanabe, Y. (2000). Washback effects of the English section of the Japanese university entrance examinations on instruction in pre-college level EFL classrooms. Language Testing Update, 27, 42-47.

West African Examination Council (WAEC) (2018). English Language Examination Syllabus.

\section{Copyrights}

Copyright for this article is retained by the author(s), with first publication rights granted to the journal.

This is an open-access article distributed under the terms and conditions of the Creative Commons Attribution license (http://creativecommons.org/licenses/by/3.0/). 